\title{
Effects of elevated temperatures and health status of the crustose coralline algae Hydrolithon boergesenii (Corallinales: Mastophoroideae) on the larval settlement of Diploria labyrinthiformis (Scleractinia: Faviinae)
}

\section{Nepsis García}

Nova Southeastern University

Maria Villalpando ( $\triangle$ mvillalpando94@gmail.com )

Fundación Dominicana de Estudios Marinos https://orcid.org/0000-0001-9764-0706

Ivan Cano

Fundación Dominicana de Estudios Marinos

\section{Rita Sellares}

Fundación Dominicana de Estudios Marinos

Aldo Croquer

The Nature Conservancy

\section{Research Article}

Keywords: Coral larval ecology, crustose coralline algae, recruitment, settlement, coral reefs

Posted Date: March 8th, 2022

DOI: https://doi.org/10.21203/rs.3.rs-1407958/v1

License: (c) (1) This work is licensed under a Creative Commons Attribution 4.0 International License. Read Full License 


\section{Abstract}

Crustose Coralline Algae (CCA) is a well-known settlement inducer for stony corals and, ultimately, recruitment, a vital component for reef growth and resilience. However, potential impacts of diseased CCA on larval settlement are not fully understood, especially on particular coral species. As oceans continue to warm, coral larvae need to be able to respond to settlement cues in elevated temperatures, yet the combined effects of thermal stress and CCA health status on larval behavior is not well known for most coral species. Here we assessed the effect of elevated temperatures and disease on the ability of the CCA Hydrolithon boergesenii to induce settlement of Diploria labyrinthiformis larvae. D. labyrinthiformis planulae were exposed to 4 substrate combinations (healthy CCA, diseased CCA, bare substratum, and bare tissue culture plate) and three temperatures $\left(27.5^{\circ} \mathrm{C}, 29^{\circ} \mathrm{C}\right.$, and $\left.31^{\circ} \mathrm{C}\right)$. Overall, settlement started earlier and was $1.5-3 x$ higher at $31^{\circ} \mathrm{C}$, regardless of CCA health status, but at this temperature, larval mortality increased two-fold in diseased CCA. Settlement differences between healthy and diseased $H$. boergesenii were only observed at $29^{\circ} \mathrm{C}$, with healthy CCA facilitating twice as much settlement and having $3 x$ lower mortality than diseased. Our findings suggest that, even though larvae can settle in both healthy and diseased CCA, temperature plays an important role in whether larvae will settle or perish. This study highlights the importance of healthy CCA to maintain and increase settlement and the ability of larvae to adapt to a warming ocean, contributing to the knowledge of $D$. labyrinthiformis larval ecology, valuable for larval rearing for restoration purposes.

\section{Introduction}

Caribbean coral populations have been declining for decades due to a combination of local and global stressors such as increasing sea surface temperatures, nutrient pollution, diseases, and coastal development (Hughes 1994; Hughes et al. 2010; de Bakker et al. 2017). Consequently, coral restoration efforts have become more widespread in recent years, acknowledging that coral reefs are unlikely to recover without human intervention (Morrison et al. 2019; Muñiz-Castillo et al. 2019). However, these efforts still produce outcomes with varying degrees of success, limited by high costs and a relatively low impact on an ecosystem level and at the spatial scales needed (Bayraktarov et al. 2016, 2019; BoströmEinarsson et al. 2020; Duarte et al. 2020).

Coral recruitment can be used as a proxy for reef resilience and recovery since it yields novel genotypes that can potentially provide greater adaptability to unfavorable conditions (Baums et al. 2019). However, for most coral species, little is known about corals' early life stages i.e., the period when these organisms have higher mortality rates (Vermeij and Sandin 2008; Doropoulos et al. 2016). This is especially true for the pre-settlement period, when larvae swim in the water column seeking an appropriate substrate to settle, since they can perish due to energy storage depletion (Vermeij 2006). Studying the early life stage ecology of specific coral species is key for understanding its contribution to the current and future composition of reefs (Chamberland et al. 2016). Therefore, identifying the factors that affect larval recruitment success can inform management decisions aimed at reducing the decline of coral reefs and improve restoration efforts through sexual propagation. 
Crustose Coralline Algae (CCA) is one of the main contributors to reef cementation and has been shown to induce coral larval settlement (Pollock et al. 2017). However, according to Quéré et al. 2015, the emergence of CCA diseases such as Coralline White Band Syndrome (CWBS) and Coralline White Patch Disease (CWPD), both significantly affected by temperature changes, can pose a real threat to corals by reducing the settlement of their offspring. Thus, the rapid emergence of diseases affecting reef organisms and the more frequent and severe bleaching events in an era of rapid ocean warming may jeopardize the natural capacity of coral reefs to recover from disturbances (Hoegh-Guldberg et al. 2007; Baker et al. 2008).

In this study, we assessed the effects of CCA health condition and high temperatures on larval settlement of the coral Diploria labyrinthiformis (Linnaeus, 1758). For this, we conducted a short-term controlled experiment on $D$. labyrinthiformis larvae exposed to different temperatures (expected summer temperatures $\left(27-28^{\circ} \mathrm{C}\right)$ and two increased temperature scenarios $\left(29^{\circ} \mathrm{C}\right.$ and $\left.31^{\circ} \mathrm{C}\right)$ ) and using healthy and diseased Hydrolithon boergesenii (Guiry and Guiry 2022) for settlement induction. We expected higher settlement rates in the presence of healthy CCA and in their optimum rearing temperature of $27.5^{\circ} \mathrm{C}$.

\section{Materials And Methods}

\section{Study species and site}

Diploria labyrinthiformis is a common coral species in the Caribbean and, depending on its location, can spawn from April to October before sunset, having a wider and earlier spawning window compared to most broadcast spawning corals in the region (Weil and Vargas 2010; Chamberland et al. 2017). D. labyrinthiformis was selected for this study due to its ability to build 3D structures in reefs, its early and multiple spawning events throughout the year, its high spawning predictability, and the contribution to recent and ongoing research regarding its reproductive potential and early life history stages (Chamberland et al. 2016). FUNDEMAR has been monitoring and documenting spawning events of this species at the Playita reef site since May 2017, producing a spawning prediction calendar for 2020 including this and 7 other coral species (Sellares-Blasco et al. 2021). Currently, there are over $150 \mathrm{D}$. labyrinthiformis adult colonies identified and tagged on this site to monitor individual colony spawning activity through time.

Hydrolithon boergesenii is a Crustose Coralline Algae (CCA) species of the subfamily Mastophoroideae that grows encrusted in the rubble and as a rhodolite in high energy shallow habitats ranging from 1-70 $m$ depth. It has a light purple coloration that can vary depending on light intensity. It is composed of small, abundant, and elevated conceptacles with a dome shape, tessellar texture, scattered trichocytes, and a single layer hypothallus (Minnery 1990; Amado-Filho et al. 2018). Several scientists have demonstrated that Hydrolithon boergesenii induces larval settlement in spawning corals such as $D$. labyrinthiformis (Quéré et al. 2015), Pseudodiploria strigosa (Ritson-Williams et al. 2016), Acropora 
cervicornis and Acropora palmata (Ritson-Williams et al. 2010); and brooding corals such as Agaricia humilis (Raimondi and Morse 2000), Favia fragum and Porites astreoides (Ritson-Williams et al. 2016).

The experiment was conducted in the Dominican Foundation for Marine Studies' (FUNDEMAR) Coral Assisted Reproduction Laboratory, located in Bayahibe, Dominican Republic (18 $21^{\prime} 57.07^{\prime \prime} \mathrm{N}$

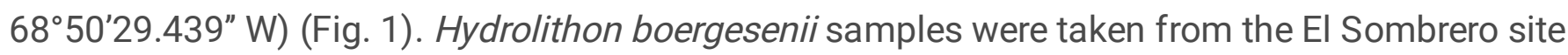
$\left(18^{\circ} 22^{\prime} 14.1^{\prime \prime} \mathrm{N} 68^{\circ} 50^{\prime} 48.3^{\prime \prime} \mathrm{W}\right)$, a highly degraded shallow reef (also a restoration site for FUNDEMARs restoration program) located $500 \mathrm{~m}$ from the coast of Bayahibe, with an average depth of $4 \mathrm{~m}$. CCA was found in high-energy areas where waves were breaking on the reef and Hydrolithon boergesenii is conspicuous. This makes it an ideal place to serve as a reference for the purpose of this study. Diploria labyrinthiformis gamete bundles were collected at the Playita site $\left(18^{\circ} 22^{\prime} 23.1^{\prime \prime} \mathrm{N} 68^{\circ} 51^{\prime} 11.7^{\prime \prime} \mathrm{W}\right)$, a local reef flat located $750 \mathrm{~m}$ from El Sombrero site and $550 \mathrm{~m}$ off the coast of Bayahibe with an average depth of $6.4 \mathrm{~m}$. This reef has a moderate relative abundance $(4.23 \pm 3.61 \%)$ and high density $\left(0.33 \pm 0.2 / \mathrm{m}^{2}\right)$ of adult $D$. labyrinthiformis colonies.

\section{Larvae production and substratum preparation}

Diploria labyrinthiformis colonies at Playita spawned on June 16, 2020, 11 nights after the full moon and 75 to 50 minutes before sunset. From the 50 colonies monitored, 17 spawned (34\%). Gamete bundles were collected from 11 colonies using funneled nets with plastic collection cups on top (Fig. S1A-B). The cups with gametes were transported to the lab and mixed together to begin fertilization. Cellular division was assessed under a dissecting microscope every 20 minutes until a fertilization rate of $96 \%$ was reached (Fig. S1C). At this stage, embryos were rinsed of excess sperm to reduce mortality.

Finally, embryos were transferred to 9 closed glass aquariums $(76.2 \mathrm{~cm} \times 30.48 \mathrm{~cm} \times 35.56 \mathrm{~cm} \mathrm{L,} \mathrm{W,} \mathrm{H}$ each) filled with filtered seawater and maintained at around $27-28^{\circ} \mathrm{C}$ for cultivation (Sellares-Blasco et al. 2021). Embryo culture maintenance was carried out daily, depending on culture condition, including lipid removal using plastic wrap and $50 \%$ water changes. Embryos reached the planulae phase approximately 21 hours after fertilization (Fig. S1D). Once larvae started to swim down the water column, around 36 hours after fertilization, individual larvae were randomly selected from a mix of samples from the 9 aquariums to use in this experiment.

Hydrolithon boergesenii was collected from Sombrero, where waves break with the reef crest. An initial visual ID of the species was done by using a Talbot $90 \mathrm{~mm} 5 \mathrm{x}$ Magnifying Glass. Then, a Pit Bull $\mathrm{CHIH058}$ Chipping Hammer was used to remove the algae from the rock and samples were placed in plastic bags. Finally, a multi-purpose mesh bag was used for transportation to the lab. The algae samples were kept in a 5-gallon Marina LED Aquarium with filtered seawater. Another visual ID was done to confirm algae species with Ritson-Williams's CCA ID Guide (2018, unpublished). After being identified, algae samples were cut to $\sim 1 \mathrm{~cm}^{2}$ with bone cutters from the DR Instruments 10FK Ultimate Coral Fragging Kit to be used as replicate substrates for the experiment.

\section{Experimental design and statistical analysis}


We performed a factorial orthogonal experiment with three factors: (1) Substrate type (4 levels of treatments), (2) temperature (3 levels of treatment) and (3) time. The experiment consisted of 9 polystyrene culture plates with 12 wells (EarthOx Life Sciences TCPN12 Sterile Non-Treated 12 Well Tissue Culture Plate). Each plate was randomly assigned with 3 replicates of 4 substrate treatments: bare substratum, calcium carbonate skeleton with large macroalgae removed but some turf algae remaining, as control (CO), healthy CCA (CCAH), diseased CCA (CCAD), and empty culture wells as procedural control (PC). Culture plates were then independently and randomly exposed to 3 temperature treatments $(27 \pm$ $0.58^{\circ} \mathrm{C}$, the optimum larval rearing temperature according to Banaszak (2018, unpublished), $29 \pm 0.43^{\circ} \mathrm{C}$, the average ocean temperature during the time of the experiment, and $31 \pm 0.28^{\circ} \mathrm{C}$, mimicking a substantial ocean warming scenario for the mid- 21 st century), placing them in a water bath inside plastic polypropylene trays with filtered seawater. The trays were connected in a closed circuit of constant flow and a titanium heater with a digital thermostat controller of $100 \mathrm{~W}$ to control the temperatures for each level. The water temperature of each system was manually measured daily every two hours from 7 am to $7 \mathrm{pm}$ using a Thomas Traceable Kangaroo digital thermometer. The time frame of these measurements was limited by a curfew stated by the national government of the Dominican Republic due to Covid-19 restriction. A graphic of the experimental layout and experiment set up is provided in Fig. 2 .

Around 36 hours after fertilization, once the larvae were competent to settle, a sample of planulae was randomly taken from each rearing aquarium, and they were all mixed in a container. A total of 10 to 12 larvae sampled randomly from this mix were assigned to each well of the 9 culture plates, resulting in 108 wells with 1,103 larvae. Data collection regarding the condition of the larvae (swimming, settled, floating, or dead) started $60 \mathrm{~h}$ after fertilization and 24 hours after the addition of larvae to the experimental set up. Condition was assessed once every morning from day 1 to day 7 , except on day 2 since, when handling for assessment, larvae that were starting to settle were observed detaching from the substrate; therefore, we decided to leave them for one day without disruption.

We classified larvae as "settled" if any degree of metamorphosis was observed, starting with skeleton formation up to tentacle formation (Fig. 3A-F). Larvae that were still alive and motile but not attached, were classified as "swimming"; metamorphosed, unattached polyps, not unusual in lab culture settings, were classified as "floating" (Miller et al. 2020; Margaret Miller pers comms)(Fig. 3F); and larvae that were absent were classified as "dead". Only settled and dead larvae were used to estimate settlement and mortality, respectively. Observations were made using a Nightsea FL-1 blue flashlight and yellow filter glasses to better locate fluorescing larvae. Settlement was confirmed under a dissecting microscope (Motic SMZ-168 Stereo Zoom microscope).

A univariate PERMANOVA based on Euclidean distance was performed to test for differences in larval settlement and mortality rates for each factor and all interactions. PERMANOVAs for settlement and mortality rates were run on untransformed percentage data using 9999 permutations under an unrestricted method and type III sum of square approach for unbalanced data. When a source of variation was significant (Pperm $<0.05$ ), we performed a two-tailed pairwise t-test to detect statistically significant differences (Anderson 2001). Test of homogeneity of dispersion was performed using 
Permdisp prior to running the Permanova test (Anderson and Walsh 2013). Dispersion of data was homogenous for each treatment.

\section{Results And Discussion}

In this study we found that Diploria labyrinthiformis larvae are affected by factors that interact to modify the outcome of settlement and/or mortality within a short period. Our results show that the interaction between time and temperature $(F=2.13, d f=10, p=0.012)$, and between CCA condition and temperature $(F=4.18, d f=6, p=0.001$, Table $1 A)$ significantly affected larval settlement. Combined, temperature, CCA condition and time explained over $63 \%$ of the total variance (Table $1 \mathrm{~A}$ ). On average, $<28 \%$ of the larvae settled within 7 days (the duration of this experiment), with significantly higher averages at day 6 and 7 at $31^{\circ} \mathrm{C}$ (Fig. 4A, Table S1).

We found that $D$. labyrinthiformis copes well in temperatures above $27.5^{\circ} \mathrm{C}$, and such an increase does not seem to affect larval performance at least for a 7-day period. On the contrary, higher settlement rates were observed in the high temperature treatment (Fig. 4, Table S1). While increased temperatures could be detrimental for larvae of some coral species before and after settlement (Bassim and Sammarco 2003), it also may increase metabolic rates and promote faster development and early settlement (Nozawa and Harrison 2007; Munday et al. 2009; Randall and Szmant 2009; Heyward and Negri 2010). Other studies have also shown higher larval settlement in stressful conditions and interpreted it as an escape attempt that may affect survival in later life stages instead of an advantage (Vermeij et al. 2006). Furthermore, some have also described a carry-over or latent effect of temperature stress, where shortterm larval survival, settlement, and metamorphosis were not affected by increased temperature, but, post-settlement, spats displayed a significant reduction in survival (Ross et al. 2013). However, in this study, post-settlement survival of $D$. labyrinthiformis spats could not be assessed since there were no surviving settlers after outplanting to an underwater nursery. Thus, future experiments with $D$. labyrinthiformis should focus on testing potential post-settlement effects of increased temperature exposure for this species.

On average, larval settlement was significantly higher for wells bearing CCA (healthy or diseased) compared to other substrates, particularly at $31^{\circ} \mathrm{C}$ treatment. Settlement on healthy over diseased CCA was only significantly higher for the $29^{\circ} \mathrm{C}$ treatment, further indicating the effect of CCA health status relies heavily on temperature (Fig. 4B, Table S1). Several species of CCA have been shown to promote settlement, while others deter it (Raimondi and Morse 2000; Ritson-Williams et al. 2009, 2016; Price 2010; Quéré et al. 2015). Diseases affecting CCA have been a concern for years because chemical cues might be compromised and/or the suitable space for settlement may become limited (Quéré and Nugues 2015; Quéré et al. 2015). Our results indicate that diseases affecting CCA hamper settlement at temperatures of $29^{\circ} \mathrm{C}$. However, thermal stress events may prompt larvae to settle regardless of CCA health status, provided these events do not prolong enough to compromise the survival of coral spats, which are often susceptible to ocean warming (Randall and Szmant 2009). Larvae rarely settled on bare substratum 
(control) and more often did so on the polystyrene culture plates (procedural control), yet $27.5^{\circ} \mathrm{C}$ was not significantly different from $31^{\circ} \mathrm{C}$ (Fig. 4B, Table S1).

In terms of mortality rates, we found significant interactions between time (days) and substrate type, and between temperature and substrate type (Table 1B, Fig. 5, Table S2). Higher mortality rates were recorded at the end of the experiment, 7 days after larvae were competent for settlement, with about $75 \%$ dead larvae in the control treatment (Fig. 5A). Moreover, an average of $<15 \%$ of the larvae died on the healthy CCA and empty culture plates (PO) treatments (Fig. 5), which shows that procedural control did not increase mortality compared to this treatment. The percentage of mortality was always significantly higher for the diseased CCA treatment compared to healthy CCA, and almost two-fold higher when compared to the CCA healthy treatment, consistent for all temperature treatments (Fig. 5B).

As for the interaction between the health status of CCA and temperature, we consistently found higher mortality rates associated with the control treatment $\left(58 \%\right.$ for $27.5^{\circ} \mathrm{C}, 46 \%$ for $29^{\circ} \mathrm{C}$ and $61 \%$ for $31^{\circ} \mathrm{C}$ ), followed by diseased CCA $\left(32 \%\right.$ for $27.5^{\circ} \mathrm{C}, 30 \%$ for $29^{\circ} \mathrm{C}$ and $15 \%$ for $\left.31^{\circ} \mathrm{C}\right)$, healthy $\operatorname{CCA}(15 \%$ for $27.5^{\circ} \mathrm{C}, 14 \%$ for $29^{\circ} \mathrm{C}$ and $13 \%$ for $31^{\circ} \mathrm{C}$ ) and the procedural control ( $<15 \%$ for all temperature treatments) (Fig. 5B). Thus, results from this study showed that within the first 7 days after reaching competence to settle, average mortality is two-four-fold higher compared to the percentage of settlement, further suggesting this period is a bottleneck of survivorship for $D$. labyrinthiformis. Other studies conducted for Caribbean (Rylaarsdam 1983; Vermeij and Sandin 2008; Alvarado-Chacon et al. 2020) and Indo Pacific corals show similar results (Babcock 1985; Babcock and Mundy 1996; Babcock et al. 2003; Wilson and Harrison 2005). Thus, our results are consistent with the finding that high mortality rates during the initial stages of their life cycle are a critical part of life-history traits in corals (Trapon et al. 2013).

In conclusion, this study shows that larval settlement of $D$. labyrinthiformis is affected by the interaction between temperature, CCA health status, and time. Settlement was highest at the last days of the study, and particularly important to note, is the reduction of settlement and increased mortality recorded for unhealthy CCA substrates. Based on this, larvae rearing practices with $D$. labyrinthiformis can be benefitted by letting larvae settle for at least 7 days and by avoiding the use of diseased CCA in cultures. Although a temperature increase did foster larval settlement regardless of CCA health state, we would not advice to rear larvae over $28^{\circ} \mathrm{C}$ since it could have potential detrimental latent or carry-over postsettlement effects that were not assessed in this study.

This study demonstrates the importance of healthy Crustose Coralline Algae communities to maintain and increase coral settlement in a warming ocean and adds to the knowledge of $D$. labyrinthiformis larval ecology under varying conditions, providing valuable information to optimize the culturing process for restoration purposes.

\section{Declarations}

\section{Funding}


This work was carried out using partial funding from The Nature Conservancy FY20-FUNDEMAR-CoralDR032020 Grant awarded to the Dominican Foundation of Marine Studies (FUNDEMAR), who also provided partial funding for this investigation. Publication costs funded by the Small Grants Programme of the Global Environment Facility ("GSP/GEF"), grant number DOM/SGP/OP6Y4/CORE/BD/2019/0, with the contribution of funds implemented by UNDP on behalf of the three Implementing Agencies of the GEF UNDP, UNEP and the World Bank - and executed by UNOPS.

\section{Competing Interests}

The authors have no relevant financial or non-financial interests to disclose.

\section{Author Contributions}

Conceptualization: [Nepsis García], [Aldo Croquer]

Methodology: [Aldo Croquer], [Nepsis García]

Formal analysis and investigation: [Nepsis García], [Maria Villalpando], [Aldo Croquer], [Iván Cano]

Writing - original draft preparation: [Nepsis García], [Maria Villalpando], [Iván Cano]

Writing - review and editing: [Maria Villalpando], [Iván Cano], [Aldo Croquer], [Nepsis García]

Funding acquisition: [Aldo Croquer], [Rita Sellares]

Resources: [Aldo Croquer], [Rita Sellares]

Supervision: [Rita Sellares], [Maria Villalpando], [Aldo Croquer]

\section{Data availability}

The datasets generated during and/or analyzed during the current study are included in this published article in the supplementary information [Supplementary File 2- Data Matrix].

\section{Ethics approval}

Coral gametes were collected under permits issued by the Dominican Republic Ministry of Environment and Natural Resources issued on June 1st, 2020. 


\section{Acknowledgments}

We thank The Nature Conservancy's Coral Program and FUNDEMAR for supporting this work and, individually, Yulissa Reyes, Rachel Plekaniec, Andreina Valdéz, Melina González and Arisaura Salcedo for their assistance in the larval rearing and data collection of this experiment. Special thanks to Rafael Fernández for his support working in the field, collecting samples and developing the experimental set-up. We also thank Sergio Guendulain for his support in the perfection of the experimental design, Raphael Ritson-Williams for his insights, advice, and inspiration on the conception of this experiment. We would also like to give special thanks to Dr. Margaret Miller for an incredibly valuable friendly review of the manuscript, providing expert insights that helped shape this work as a whole.

\section{References}

Alvarado-Chacon EM, Gómez-Lemos LA, Sierra-Sabalza NP, Hernández-Chamorro AM, Lozano-Peña JP, Valcárcel-Castellanos CA, Pizarro V, García-Urueña R, Zárate-Arévalo JC, Rojas JA (2020) Early life history of the caribbean coral Orbicella faveolata (Scleractinia: Merulinidae). Rev Biol Trop 68:1262-1274. https://doi.org/10.15517/RBT.V6814.40805

Amado-Filho GM, Bahia RG, Mariath R, Jesionek MB, Moura RL, Bastos AC, Pereira-Filho GH, FranciniFilho RB (2018) Spatial and temporal dynamics of the abundance of crustose calcareous algae on the southernmost coral reefs of the western atlantic (Abrolhos Bank, Brazil). Algae 33:85-99. https://doi.org/10.4490/algae.2018.33.2.25

Anderson MJ, Walsh DCI (2013) PERMANOVA, ANOSIM, and the Mantel test in the face of heterogeneous dispersions: What null hypothesis are you testing? Ecol Monogr 83:557-574. https://doi.org/10.1890/122010.1

Babcock R, Mundy C (1996) Coral recruitment: Consequences of settlement choice for early growth and survivorship in two scleractinians. J Exp Mar Bio Ecol 206:179-201. https://doi.org/10.1016/S00220981(96)02622-6

Babcock RC (1985) Growth and mortality in juvenile corals (Goniastrea, Platygyra and Acropora) in the first year. Proc. 5th Int. Coral Reef Symp. 355-360.

Babcock RC, Baird AH, Piromvaragorn S, Thomson DP, Willis BL (2003) Identification of scleractinian coral recruits from Indo-Pacific reefs. Zool Stud 42:211-226.

Baker AC, Glynn PW, Riegl B (2008) Climate change and coral reef bleaching: An ecological assessment of long-term impacts, recovery trends and future outlook. Estuar Coast Shelf Sci 80:435-471. https://doi.org/10.1016/j.ecss.2008.09.003 
Bassim KM, Sammarco PW (2003) Effects of temperature and ammonium on larval development and survivorship in a scleractinian coral (Diploria strigosa). Mar Biol 142:241-252.

https://doi.org/10.1007/s00227-002-0953-z

Baums IB, Baker AC, Davies SW, Grottoli AG, Kenkel CD, Kitchen SA, Kuffner IB, LaJeunesse TC, Matz M V., Miller MW, Parkinson JE, Shantz AA (2019) Considerations for maximizing the adaptive potential of restored coral populations in the western Atlantic. Ecol Appl 29(8):e01978.

https://doi.org/10.1002/eap.1978

Bayraktarov E, Saunders MI, Abdullah S, Mills M, Beher J, Possingham HP, Mumby PJ, Lovelock CE (2016) The cost and feasibility of marine coastal restoration. Ecol Appl 26(4): 1055-1074.

https://doi.org/10.1890/15-1077

Bayraktarov E, Stewart-Sinclair PJ, Brisbane S, Boström-Einarsson L, Saunders MI, Lovelock CE, Possingham HP, Mumby PJ, Wilson KA (2019) Motivations, success, and cost of coral reef restoration. Restor. Ecol. 27(5):981-991. https://doi.org/10.1111/rec.12977

Boström-Einarsson L, Babcock RC, Bayraktarov E, Ceccarelli D, Cook N, Ferse SCA, Hancock B, Harrison P, Hein M, Shaver E, Smith A, Suggett D, Stewart-Sinclair PJ, Vardi T, McLeod IM (2020) Coral restoration - A systematic review of current methods, successes, failures and future directions. PLoS One 15(1):e0226631. https://doi.org/10.1371/journal.pone.0226631

Chamberland VF, Petersen D, Latijnhouwers KRW, Snowden S, Mueller B, Vermeij MJA (2016) Four-yearold Caribbean Acropora colonies reared from field-collected gametes are sexually mature. Bull Mar Sci 92:263-264. https://doi.org/10.5343/bms.2015.1074

Chamberland VF, Snowden S, Marhaver KL, Petersen D, Vermeij MJA (2017) The reproductive biology and early life ecology of a common Caribbean brain coral, Diploria labyrinthiformis (Scleractinia: Faviinae). Coral Reefs 36:83-94. https://doi.org/10.1007/s00338-016-1504-2

de Bakker DM, van Duyl FC, Bak RPM, Nugues MM, Nieuwland G, Meesters EH (2017) 40 Years of benthic community change on the Caribbean reefs of Curaçao and Bonaire: the rise of slimy cyanobacterial mats. Coral Reefs 36(2):355-367. https://doi.org/10.1007/s00338-016-1534-9

Doropoulos C, Roff G, Bozec YM, Zupan M, Werminghausen J, Mumby PJ (2016) Characterizing the ecological trade-offs throughout the early ontogeny of coral recruitment. Ecol Monogr 86:20-44. https://doi.org/10.1890/15-0668.1

Duarte CM, Agusti S, Barbier E, Britten GL, Castilla JC, Gattuso JP, Fulweiler RW, Hughes TP, Knowlton N, Lovelock CE, Lotze HK, Predragovic M, Poloczanska E, Roberts C, Worm B (2020) Rebuilding marine life. Nature 580(7801):39-51. https://doi.org/10.1038/s41586-020-2146-7 
Guiry, M.D. \& Guiry, G.M. (2022). AlgaeBase. World-wide electronic publication, National University of Ireland, Galway (taxonomic information republished from AlgaeBase with permission of M.D. Guiry). Hydrolithon boergesenii (Foslie) Foslie, 1909. World Register of Marine Species. https://www.marinespecies.org/aphia.php?p=taxdetails\&id=372893 Accessed 28 February 2022.

Heyward AJ, Negri AP (2010) Plasticity of larval pre-competency in response to temperature: Observations on multiple broadcast spawning coral species. Coral Reefs 29:631-636. https://doi.org/10.1007/s00338-009-0578-5

Hoegh-Guldberg O, Mumby PJ, Hooten AJ, Steneck RS, Greenfield P, Gomez E, Harvell CD, Sale PF, Edwards AJ, Caldeira K, Knowlton N, Eakin CM, Iglesias-Prieto R, Muthiga N, Bradbury RH, Dubi A, Hatziolos ME (2007) Coral reefs under rapid climate change and ocean acidification. Science 318(5857):1737-1742. https://doi.org/10.1126/science.1152509

Hughes TP (1994) Catastrophes, phase shifts, and large-scale degradation of a Caribbean coral reef. Science 265(5178):1547-1551. https://doi.org/10.1126/science.265.5178.1547

Hughes TP, Graham NAJ, Jackson JBC, Mumby PJ, Steneck RS (2010) Rising to the challenge of sustaining coral reef resilience. Trends Ecol. Evol. 25(11):633-

642. https://doi.org/10.1016/j.tree.2010.07.011

Joseph Pollock F, Katz SM, van de Water JAJM, Davies SW, Hein M, Torda G, Matz M V., Beltran VH, Buerger P, Puill-Stephan E, Abrego D, Bourne DG, Willis BL (2017) Coral larvae for restoration and research: A large-scale method for rearing Acropora millepora larvae, inducing settlement, and establishing symbiosis. PeerJ 5:e3732. https://doi.org/10.7717/peerj.3732

Miller MW, Bright AJ, Pausch RE, Williams DE (2020) Larval longevity and competency patterns of Caribbean reef-building corals. PeerJ 8:e9705. https://doi.org/10.7717/peerj.9705

Minnery GA (1990) Crustose coralline algae from the Flower Garden Banks, northwestern Gulf of Mexico: controls on distribution and growth morphology. J Sediment Petrol 60:992-1007. doi: 10.1306/D42676632B26-11D7-8648000102C1865D

Morrison TH, Hughes TP, Adger WN, Brown K, Barnett J, Lemos MC (2019) Save reefs to rescue all ecosystems. Nature 573:333-336

Munday PL, Leis JM, Lough JM, Paris CB, Kingsford MJ, Berumen ML, Lambrechts J (2009) Climate change and coral reef connectivity. Coral Reefs 28:379-395. https://doi.org/10.1007/s00338-008-0461-9

Muñiz-Castillo Al, Rivera-Sosa A, Chollett I, Eakin CM, Andrade-Gómez L, McField M, Arias-González JE (2019) Three decades of heat stress exposure in Caribbean coral reefs: a new regional delineation to enhance conservation. Sci Rep 9(1):1-14. https://doi.org/10.1038/s41598-019-47307-0 
Nozawa Y, Harrison PL (2007) Effects of elevated temperature on larval settlement and post-settlement survival in scleractinian corals, Acropora solitaryensis and Favites chinensis. Mar Biol 152:1181-1185. https://doi.org/10.1007/s00227-007-0765-2

Price N (2010) Habitat selection, facilitation, and biotic settlement cues affect distribution and performance of coral recruits in French Polynesia. Oecologia 163:747-758.

https://doi.org/10.1007/s00442-010-1578-4

Quéré G, Nugues MM (2015) Coralline algae disease reduces survival and settlement success of coral planulae in laboratory experiments. Coral Reefs 34:863-870. https://doi.org/10.1007/s00338-015-1292-0

Quéré G, Meistertzheim AL, Steneck RS, Nugues MM (2015) Histopathology of crustose coralline algae affected by white band and white patch diseases. PeerJ 3:e1034. https://doi.org/10.7717/peerj.1034

Raimondi PT, Morse ANC (2000) The consequences of complex larval behavior in a coral. Ecology 81:3193-3211. https://doi.org/10.1890/0012-9658(2000)081[3193:TCOCLB]2.0.CO;2

Randall CJ, Szmant AM (2009) Elevated temperature affects development, survivorship, and settlement of the elkhorn coral, Acropora palmata (Lamarck 1816). Biol Bull 217:269-282.

https://doi.org/10.1086/BBLv217n3p269

Ritson-Williams R, Arnold S, Fogarty N, Steneck RS, Vermeij M, Paul VJ (2009) New perspectives on ecological mechanisms affecting coral recruitment on reefs. Smithson Contrib Mar Sci 437-457. https://doi.org/10.5479/si.01960768.38.437

Ritson-Williams R, Paul VJ, Arnold SN, Steneck RS (2010) Larval settlement preferences and postsettlement survival of the threatened Caribbean corals Acropora palmata and A. cervicornis. Coral Reefs 29:71-81. https://doi.org/10.1007/s00338-009-0555-z

Ritson-Williams R, Arnold SN, Paul VJ (2016) Patterns of larval settlement preferences and postsettlement survival for seven Caribbean corals. Mar Ecol Prog Ser 548:127-138. https://doi.org/10.3354/meps11688

Ross C, Ritson-Williams R, Olsen K, Paul VJ (2013) Short-term and latent post-settlement effects associated with elevated temperature and oxidative stress on larvae from the coral Porites astreoides. Coral Reefs 32:71-79. https://doi.org/10.1007/s00338-012-0956-2

Rylaarsdam K (1983) Life histories and abundance patterns of colonial corals on Jamaican reefs. Mar Ecol Prog Ser 13:249-260. https://doi.org/10.3354/meps013249

Sellares-Blasco RI, Villalpando MF, Guendulain-García SD, Croquer A (2021) Assisted Coral Reproduction in the Dominican Republic: A Successful Story to Replicate in the Caribbean. Front Mar Sci 8:669505. https://doi.org/10.3389/fmars.2021.669505 
Trapon ML, Pratchett MS, Adjeroud M, Hoey AS, Baird AH (2013) Post-settlement growth and mortality rates of juvenile scleractinian corals in Moorea, French Polynesia versus Trunk Reef, Australia. Mar Ecol Prog Ser 488:157-170. https://doi.org/10.3354/meps10389

Vermeij MJA (2006) Early life-history dynamics of Caribbean coral species on artificial substratum: The importance of competition, growth and variation in life-history strategy. Coral Reefs 25(1):59-

7. https://doi.org/10.1007/s00338-005-0056-7

Vermeij MJA, Sandin SA (2008) Density-dependent settlement and mortality structure the earliest life phases of a coral population. Ecology 89:1994-2004. https://doi.org/10.1890/07-1296.1

Vermeij MJA, Fogarty ND, Miller MW (2006) Pelagic conditions affect larval behavior, survival, and settlement patterns in the Caribbean coral Montastraea faveolata. Mar Ecol Prog Ser 310:119-128. https://doi.org/10.3354/meps310119

Weil E, Vargas WL (2010) Comparative aspects of sexual reproduction in the caribbean coral genus Diploria (Scleractinia: Faviidae). Mar Biol 157:413-426. https://doi.org/10.1007/s00227-009-1328-5

Wilson J, Harrison P (2005) Post-settlement mortality and growth of newly settled reef corals in a subtropical environment. Coral Reefs 24:418-421. https://doi.org/10.1007/s00338-005-0033-1

\section{Tables}

Table 1. PERMANOVA results of A) larval settlement and B) larval mortality testing for differences between Substrate type (Su), Days ( $\mathrm{Da}$ ) and Temperature $(\mathrm{Te})$ treatments and their interactions. 


\begin{tabular}{|llllllll|}
\hline A. SETTLEMENT & & & & & & & \\
\hline Source & df & SS & MS & Pseudo-F & P(perm) & perms & CV\% \\
\hline Substrate & 3 & 8062.4 & 2687.5 & 34.554 & 0.001 & 998 & 16.26337 \\
\hline Days & 5 & 10146 & 2029.2 & 26.091 & 0.001 & 999 & 17.22452 \\
\hline Temperature & 2 & 4489 & 2244.5 & 28.859 & 0.001 & 998 & 12.8337 \\
\hline SuxDa & 15 & 1374.6 & 91.639 & 1.1783 & 0.278 & 997 & 2.903589 \\
\hline SuxTe & 6 & 1954.4 & 325.74 & 4.1882 & 0.001 & 999 & $\mathbf{8 . 6 8 3 1 7 2}$ \\
\hline DaxTe & 10 & 1663.6 & 166.36 & 2.139 & 0.012 & 998 & 6.356476 \\
\hline SuxDaxTe & 30 & 1515.8 & 50.525 & 0.64964 & 0.923 & 998 & 0 \\
\hline Residual & 576 & 44798 & 77.775 & & & & 35.73517 \\
\hline Total & 647 & 74004 & & & & & \\
\hline B. MORTALITY & & & & & & & \\
\hline Substrate & 3 & $2.16 \mathrm{E}+05$ & 71902 & 169.67 & 0.001 & 999 & 28.01462 \\
\hline Days & 5 & $1.05 \mathrm{E}+05$ & 21093 & 49.773 & 0.001 & 999 & 18.45057 \\
\hline Temperature & 2 & 3242.4 & 1621.2 & 3.8256 & 0.016 & 999 & 3.140225 \\
\hline SuxDa & 15 & 47745 & $\mathbf{3 1 8 3}$ & $\mathbf{7 . 5 1 1}$ & $\mathbf{0 . 0 0 1}$ & 999 & $\mathbf{1 3 . 4 8 2 5}$ \\
\hline SuxTe & $\mathbf{6}$ & $\mathbf{1 8 8 3 0}$ & $\mathbf{3 1 3 8 . 4}$ & $\mathbf{7 . 4 0 5 8}$ & $\mathbf{0 . 0 0 1}$ & 998 & $\mathbf{9 . 4 5 6 2 8 6}$ \\
\hline DaxTe & 10 & 1654.7 & 165.47 & 0.39047 & 0.935 & 999 & 0 \\
\hline SuxDaxTe & 30 & 7382.8 & 246.09 & 0.58071 & 0.965 & 997 & 0 \\
\hline Residual & 576 & $2.44 \mathrm{E}+05$ & 423.78 & & & & 27.4558 \\
\hline Total & 647 & $6.44 \mathrm{E}+05$ & & & & & \\
\hline
\end{tabular}

\section{Figures}




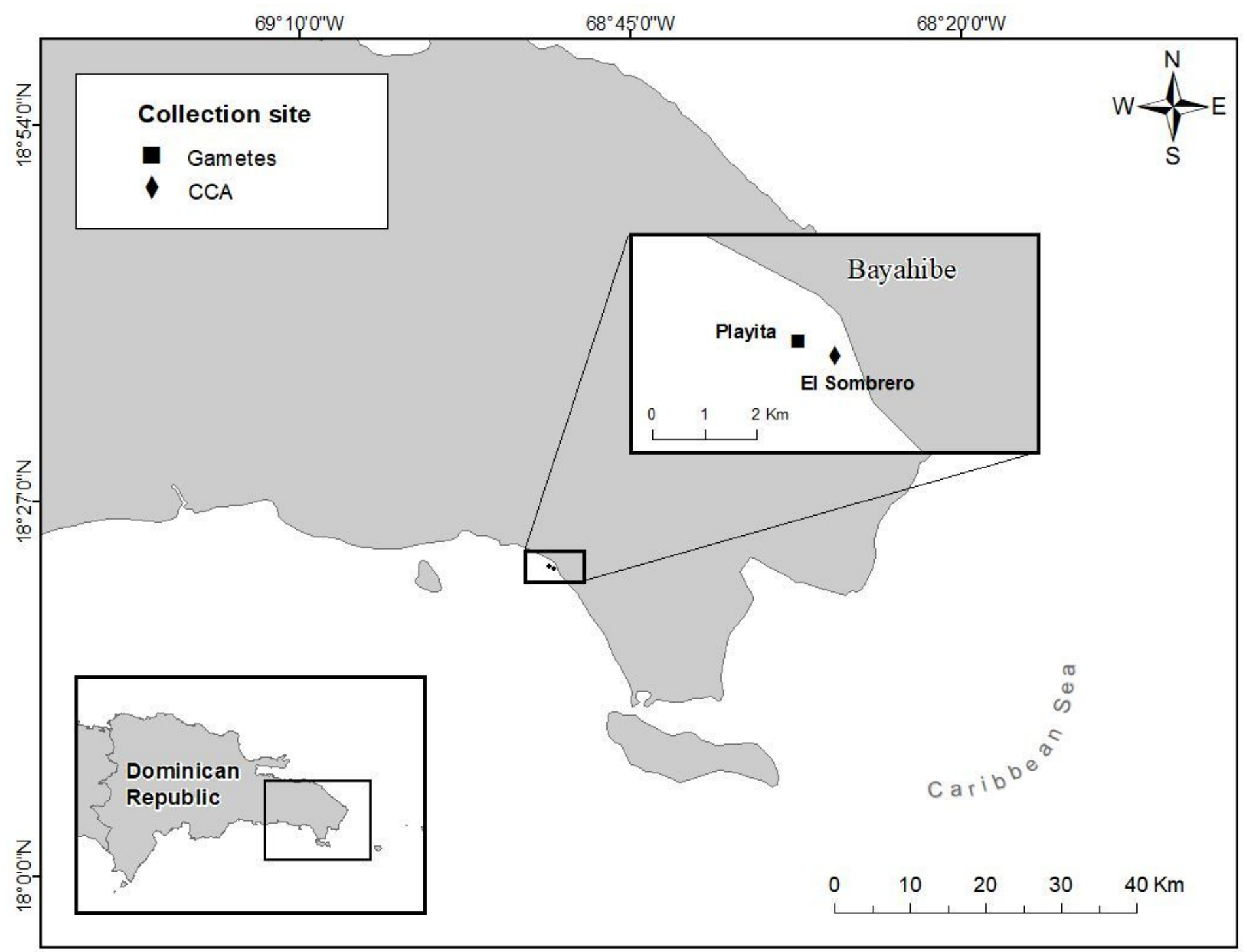

Figure 1

Map of southeastern Dominican Republic indicating the location of El Sombrero and Playita site where crustose coralline algae samples and gametes from Diploria labyrinthiformis were collected, respectively. 


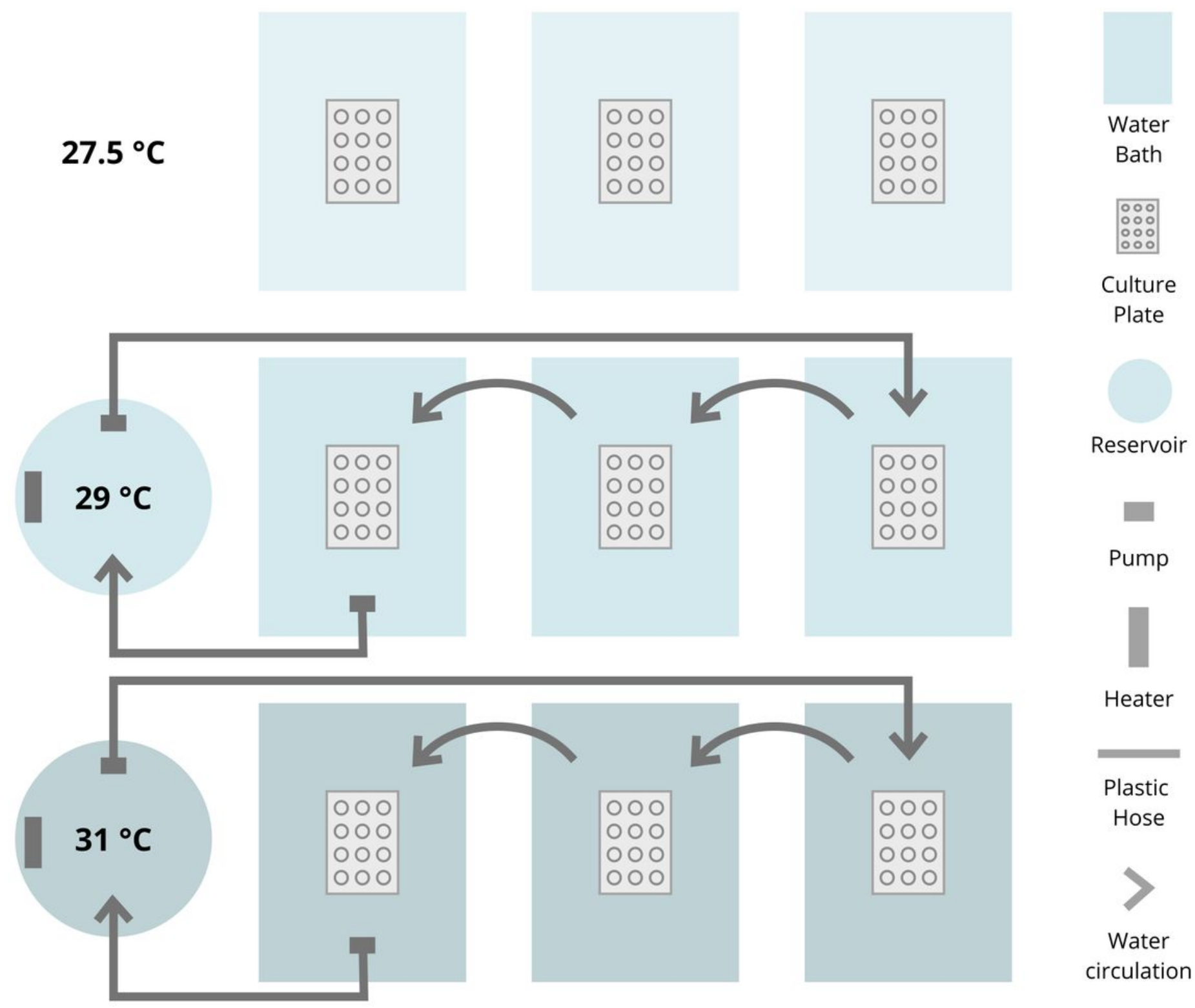

Figure 2

Experimental design and study set up. Substratum treatments (bare substratum as control (CO), healthy CCA (CCAH), diseased CCA (CCAD), and empty culture wells as procedural control (PC)) were replicated 3 times and randomly allocated within each polystyrene culture plate. Each plate was placed in an individual water tray with the different temperature treatment levels (ambient $27.5^{\circ} \mathrm{C}, 29^{\circ} \mathrm{C}$, and $31^{\circ} \mathrm{C}$ ), each replicated 3 times. The trays with the same temperature treatment were connected to a reservoir where the water temperature was maintained by a heater. 


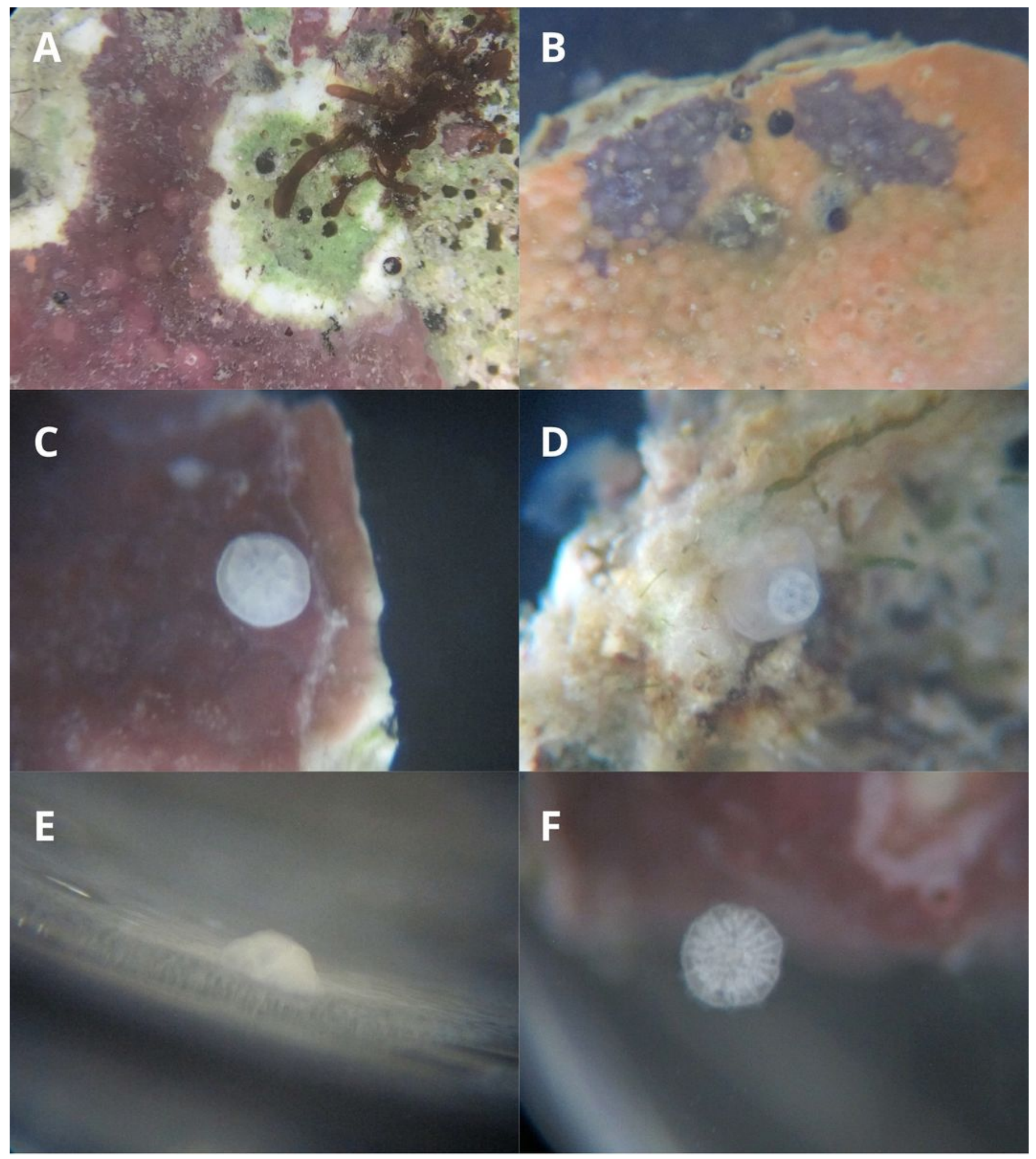

\section{Figure 3}

Substrate types provided to larvae: A and B) Diseased Hydrolithon boergesenii Crustose Coralline Algae (CCAD), C) Healthy CCA (CCAH), D) Bare substratum or calcium carbonate skeleton removed of large macroalgae with some turf algae remaining. Examples of larvae condition: C, D and E) settled and metamorphosed and F) metamorphosed, unattached polyps in the water column. 

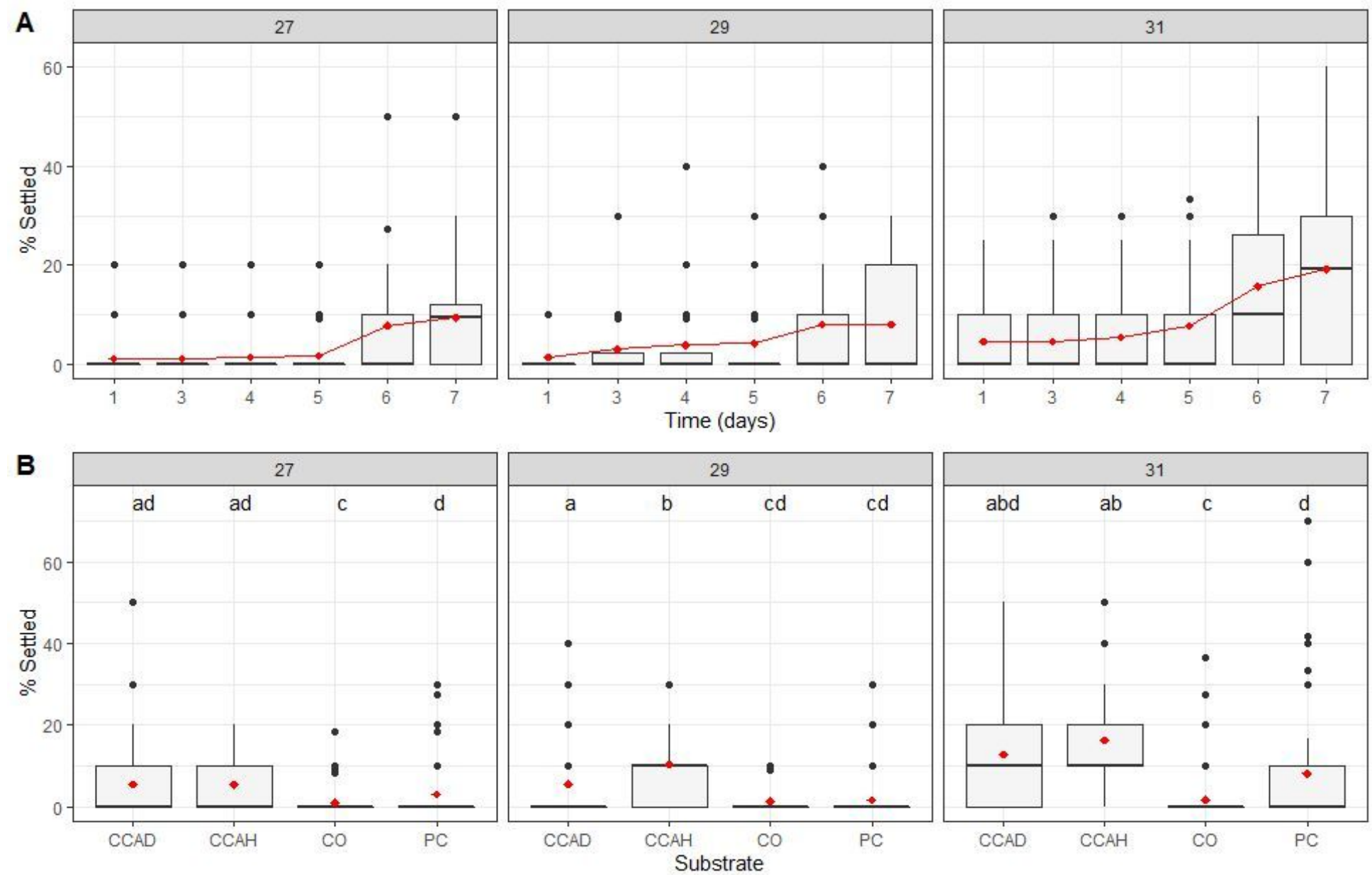

Figure 4

Settlement percentage of $D$. labyrinthiformis larvae in function of $A$ ) the seven days of the experiment and $B$ ) across experimental treatments $(C C A D=$ Diseased crustose coralline algae, $C C A H=H e a l t h y$ crustose coralline algae, $\mathrm{CO}=$ Control, $\mathrm{PC}=$ Procedural control). Letters denote significant differences among experimental treatments from a post-hoc analysis. In both panels, red dots represent the mean values. 

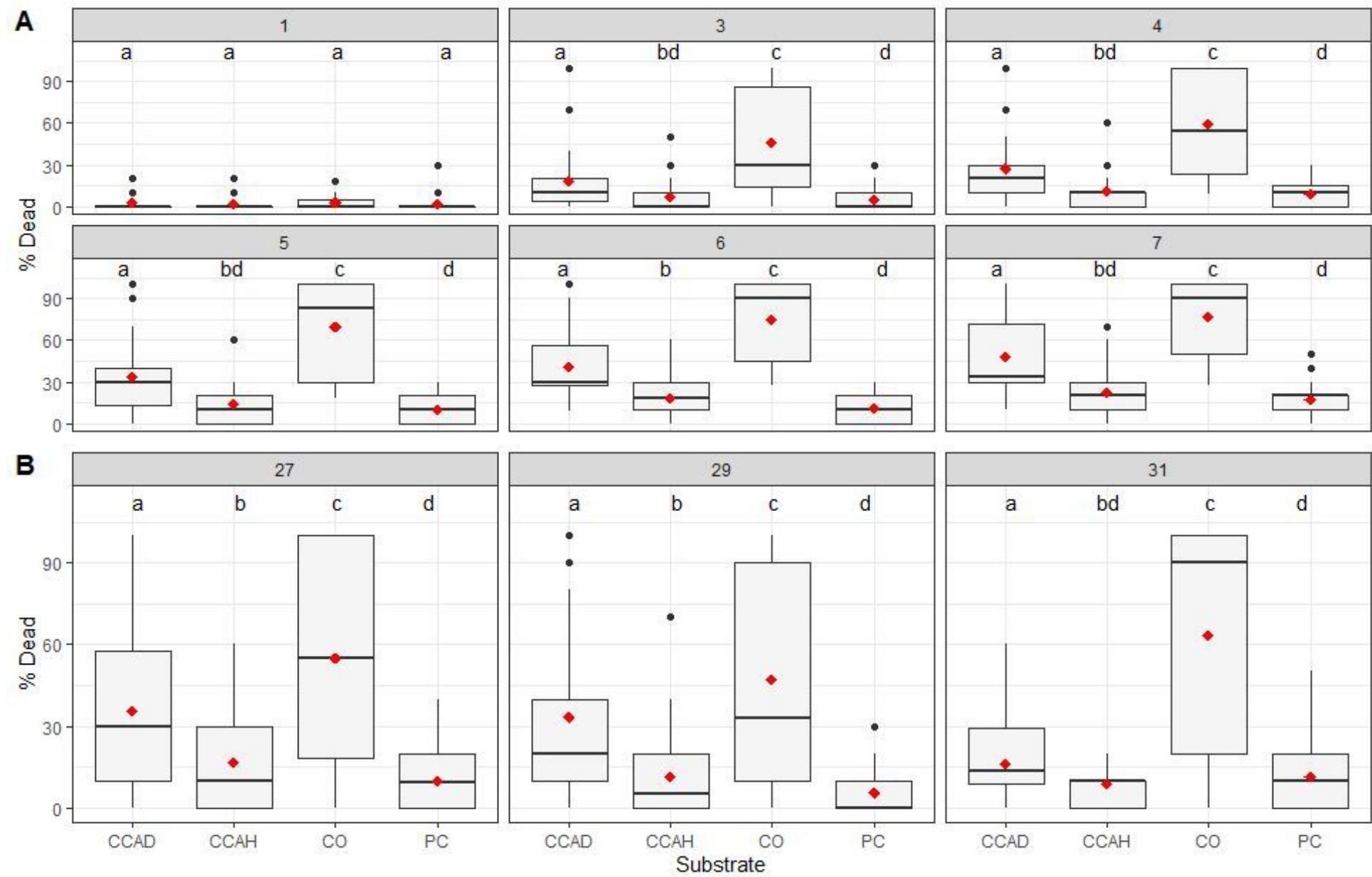

Figure 5

Percent mortality of $D$. labyrinthiformis larvae in function of $A$ ) treatments and the seven days of the experiment and $\mathrm{B})$ across experimental treatments $(C C A D=$ Diseased crustose coralline algae, $\mathrm{CCAH}=$ Healthy crustose coralline algae, $\mathrm{CO}=$ Control, $\mathrm{PC}=$ Procedural control). Letters denote significant differences among experimental treatments from a post-hoc analysis. In both panels, red dots represent the mean values.

\section{Supplementary Files}

This is a list of supplementary files associated with this preprint. Click to download.

- SupplementaryFile1.docx

- SupplementaryFile2DataMatrix.xIsx 